J O U R N A O F

French and Francophone Philosophy
REV UE DE LA

philosophie française et de langue française

\title{
Active Viewership and Ethical Representation: Responsible Spectatorship in Alfredo Jaar's “Real Pictures" and Gil Courtemanche's Un dimanche à la piscine à Kigali
}

Angela Ritter

Journal of French and Francophone Philosophy - Revue de la philosophie française et de langue française, Vol XXIV, No 1 (2016) 205-223.

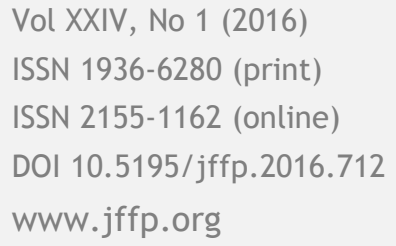

\section{(c) EY-NC-NO}

This work is licensed under a Creative Commons Attribution-Noncommercial-No Derivative Works 3.0 United States License.

\section{ULLS

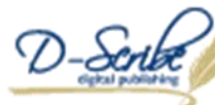

This journal is operated by the University Library System of the University of Pittsburgh as part of its D-Scribe Digital Publishing Program, and is co-sponsored by the University of Pittsburgh Press 


\title{
Active Viewership and Ethical Representation
}

\author{
Responsible Spectatorship in Alfredo Jaar's "Real \\ Pictures" and Gil Courtemanche's Un dimanche à la \\ piscine à Kigali
}

\author{
Angela Ritter \\ University of North Carolina, Chapel HIll
}

In its discussion of Gil Courtemanche's Un dimanche à la piscine à Kigali and Alfredo Jaar's installation of "Real Pictures," both of which are representations of the Rwandan Genocide, this analysis contributes to a larger discussion on ethical representations of violence. Generally the discussion of the ethics of representation analyzes the ways in which the author or artist portrays the violent events. It focuses on the importance of the historical and political context when describing the events, as well as on the ways in which the author or artist avoids the potential objectifying or dehumanizing effects of representations on the victims, as well as, the perpetrators. This article highlights another important element to be considered in the study of ethical representations- that of how the reader is engaged in the representation and as a result may or may not contribute to stereotypes, objectification, and other negative consequences possible when representing violence. Those who represent violence must not only consider ethical implications with their own interactions with the event and text or image, but also how they encourage their audience to interact with them.

While the Rwandan Genocide was virtually absent from the news during the months of violence in the spring of 1994, there have since been many photos, films, books and news reports representing the atrocities- one could even claim an inundation of representations of the genocide. However, often film, literary, media, and photographic representations of the Rwandan genocide do not reveal the full complexity of the events; they simplify the realities of the genocide and often work to further degrade and victimize the Rwandans implicated. This can be especially true in visual 
representations of genocide such as photos portrayed by the media or in artistic representations.

Visual depictions of the violence create the understanding that Western audiences possess of genocide, and they too often reduce the complexity of the situation and even hide the truth behind the events from the viewers. Baudrillard aptly explains the power of the image in the postmodern world: "Habituellement, dans notre univers médiatique, l'image est là à la place de l'événement. Elle s'y substitue, et la consommation de l'image épuise l'événement par procuration." "Usually, in our mediacentered world, the image is there in place of the event. It substitutes itself for the event, and the consumption of the image wears out the event by proxy." 1 This replacement of the event by the representations of the event can be dangerous both for the viewers who accept the portrayal of victims and aggressors, and for the victims themselves who are often further degraded. Too often representations of genocide in the media are limited to obscene, degrading, and objectifying images, thus rendering the event itself a spectacle. While these representations are not necessarily inaccurate, they do provide a limited view of genocide and of the people associated with the events, which can conceptually transform people into objects. This transformation is unethical in nature, perpetuates the stereotypes and biases that fuel hatred and violence, and is the very essence of what representations should try to avoid. Yet, often photographers, journalists, artists and writers fall short in their responsibility to ethically represent the violence witnessed.

In his November 1994 article Un génocide sans images. Blancs filment Noirs. published in Le Monde Diplomatique, Edgar Roskis, a French journalist, discusses the questionable choices of journalists and photographers as they seek to get their "shot". In his article he offers specific examples of photographers and journalists unethically representing the genocide, and even purposefully exploiting the situation and images in order to profit. Among these examples he includes a quotation from a fellow French journalist Jean-Michel Turpin of the Gamma agency. Turpin was in Zaire at the end of the genocide taking photographs of Rwandan refugees along with many other journalists. He personally regretted a photo that he took, and in the following citation he further laments the challenges of photographers and the tendency to go too far:

Writers can do their jobs more discreetly, but when you work with a camera, you have to get up very close to your subjects and look them in the face. You have to get into some positions that are going to be grotesque...I saw a photographer who was almost sitting on top of a dead child to get a shot. He obviously hadn't realized it, but at that point, I had had enough. ${ }^{2}$

Roskis supports his colleague's concerns about unethical choices of journalists and chooses to incorporate the quote into his article to express 
multiple, similar perspectives. He goes further in discussing the exploitative measures taken as he explains that the majority of the images engraved in Western memory of the Rwandan genocide were actually taken from Zaire in the safe humanitarian zone created by the French.

[This gave] photo stylists and other photo award hunters [a] convenient location where they could instantly access an inexhaustible supply of the raw materials they need to produce images of Africa for Western consumption: large anonymous groups of people floating through ethereal clouds of dust; the beautiful bodies of the ill and injured; the wide, imploring eyes of children; infants latched on to their mother's empty- or with a bit of luck, her dead- breast. ${ }^{3}$

Roskis refers to journalists and photographers as "photo award hunters" in order to emphasize profiteering behaviors. He discusses the images in terms of consumption in order to underline the unethical use of the images. Also, Roskis gives examples of the types of photos that were being taken while illuminating the exploitative, de-humanizing ways in which people take and show pictures of violence. Furthermore, Roskis equates the representation of genocide to a marketplace and in so doing implies questionable ethics. With these commentaries on photography following the Rwandan genocide, he also participates in a larger discussion of how violence should be captured and portrayed. Yet, the shock value goal of photography has been fully embraced both by media and by NGOs because it sells to the general public.

Also, Roskis questions the ultimate effectiveness of the images in representing the genocide. While obscene, pornographic-like ${ }^{4}$ images gain attention because they shock the public, he argues that "at best these images of the dead and dying attract our charity. They don't keep us from living or even from sleeping at night." 5 Roskis questions the efficacy in the representations of genocide and highlights the continued indifference of the international public. As a journalist himself, he does place significant responsibility on the role of the media in shaping public opinion, and it seems that in the case of Rwanda there was a failure to justly represent the violence. Susan Sontag, who is not a journalist but a human rights activist, an author, and a literary critic who has done significant research on representations of suffering and violence, shares a similar perspective to Roskis about the important role that media holds in our society but also the ineffectiveness of its representations. She describes photographs as a "means of making 'real' (or 'more real') matters that the privileged and the merely safe might prefer to ignore" 6 , thus insinuating their illuminating importance. Yet, she also acknowledges that the desired response of viewers is not attained-instead the images are dismissed and people continue on with their lives. Sontag echoes Virginia Woolf's perspective on the people's failure to respond to the images: it is not because we are "moral monsters" but rather, "our failure is one of imagination, of empathy: we have failed to 
hold this reality (the war, violence, or suffering) in mind"7. If the inaction is a result of a failure of imagination and empathy, then representations must strive to engage their viewer/reader's in such a way that this does not occur, which is exactly what Jaar and Courtemanche do.

Many journalists including Edgar Roskis, Jean-Michel Turpin, and Tom Giles, who wrote for BBC, condemn the ways in which the genocide in Rwanda was, and was not ${ }^{8}$, represented in the media. They join their voices with literary critics such as Susan Sontag, Edward Said, or Cecile Lavergne who question the ethical implications in how images and texts portray suffering and marginalized groups of people in literature and art. However, it is not only the authors and artists who represent the violence that run the risk of further objectifying the people they discuss. The readers and viewers can also participate in dehumanization because of the way in which they interact with the representations. Therefore, when considering ethical representations of violence it is important to also consider the role of the reader. This is a difficult task as each reader may relate differently to a text. However, it is beneficial to analyze the ways in which the representations do, or do not, seek to include the viewer or reader in the process of understanding, as well as how the representation encourages the reader or audience to interact with the event and/or people. This is a new dimension to the studies of ethical representation: the artist, writer, journalist not only has to be aware and cautious of how he depicts violence, victims, perpetrators, etc. but is also ethically implored to consider the strategies he uses to implicate the reader and encourage ethical spectatorship.

Alfredo Jaar and Gil Courtemanche both exemplify this aspect of ethical representation as they require the reader to interact with the subject of genocide with compassion and honest reflection regarding the complexity of the events as well as the failure of humanity at multiple levels. Neither Jaar nor Courtemanche allow their audience to retain a distant, detached, or arrogant position regarding the violence that tore apart a nation and killed hundreds of thousands of people.

Alfredo Jaar is a Chilean photographer who travelled to Rwanda directly after the genocide in order to gather eye-witness accounts and document photographically what had occurred. After his return from Rwanda, he created many different photographic installations about Rwanda and the genocide, none of which would be considered traditional. He found creative ways to handle the challenges around representing such violence, challenges such as whether the image further dehumanizes the victim, or if by taking the photo the photographer participates in the exploitation of the "other". His "Real Pictures" installation in Chicago in January 1995 was a creative and poignant response to these ethical dilemmas: he actually chose not to use his photographs in his installation. While Jaar was in Rwanda he snapped thousands of pictures, but in this first installation not one of the photographs was seen by the viewers because he 
was so dissatisfied with the limitations of the photographs to portray what he saw, heard, and experienced there. Even when taking the photos he struggled as he felt that he could not do justice to what he was seeing and hearing. Upon his return he continued to wrestle with how to best use his images in representation of the genocide. Jaar is quoted in Ruben Gallo's article Representation of Violence, Violence of Representation where he admits the challenges he faced in Rwanda as he tried to capture all he saw:

For me, what was important was to record everything I saw around me, and to do this as methodically as possible. In these circumstances a 'good photograph' is a picture that comes as close as possible to reality. But the camera never manages to record what your eyes se, or what you feel at the moment. The camera always creates a new reality. I have always been concerned with the disjunction between experience and what can be recorded photographically. In the case of Rwanda, the disjunction was enormous and the tragedy un-representable. This is why it was so important for me to speak with people, to record their words, their ideas, their feelings. I discovered that the truth of the tragedy was in the feelings, words, and ideas of those people, and not in the pictures. ${ }^{9}$

Jaar took thousands of pictures but was displeased with his inability to capture the extent of the suffering and the humanity of the victims and aggressors. He did not want to be reductionist in his representation like so many others have been, and so he chose not to exhibit his work.

Stéphane Audouin-Rouzeau, in his article Violences extrêmes de combat et refus de voir, speaks positively regarding Jaar's choice not to display his images from Rwanda in the 1995 installation. He praises the choice as an implicitly moral decision as he discusses the perils of voyeurism and the spectacle of violence.

N'est-ce pas, au moins en filigrane, le péril de voyeurisme dont on paraît se méfier, la jouissance toujours possible face au spectacle de la violence et de son érotisation? L'étude de la violence de combat se situerait-elle du côté de l'exhibitionnisme, de l'obscénité, voire de la perversité toujours à redouter de la part de celui qui la dévoile, par la parole ou par l'écriture? Auquel cas, le refus de voir $\mathrm{s}^{\prime}$ adosserait à une posture implicitement moralisatrice. ${ }^{10}$

Is it not, at least implicitly, the peril of voyeurism that we seem to mistrust, the pleasure always possible in face of the spectacle of violence and its eroticization? The study of combat violence is situated next to exhibitionism, obscenity, or even the perversity that is always feared by that which unveils it through words or writing. In which case, the refusal to see would back up against an implicitly moral posture. 
Rouzeau claims that the best choice in facing ethical questions of representation is to refuse to look at the degrading images. He situates the study of violence next to exhibitionism, and thus believes that seeing is always a voyeuristic act. Contrary to Rouzeau, I would argue that while observing representations of violence can be voyeuristic in nature, refusing to look at and acknowledge the suffering that occurs is a limited solution. There is value to the sharing and preservation of stories. This importance of witnessing, and the healing aspect involved, is denied if there is an unwilling audience. This, thus, begs the question of how one sees and does so ethically. In addition to concern on the part of the author, photographer, journalist, etc. to responsibly portray the violence, Rouzeau implicitly suggests the importance of a conscientious viewer or reader who refuses to fall prey to the exhibitionist shock of violence portrayed or to be part of an objectification or dehumanization of victims.

Jaar wanted to avoid rendering the genocide into a spectacle of images, thus dehumanizing the victims portrayed, but he was also greatly concerned with the lack of effectiveness of images in stirring empathetic responses. He lamented the inaction of people after seeing the images during the genocide and wondered how he could inspire a different response. Roland Barthes explains the erosion of power and effectiveness in images and representations by suggesting that "it is not enough to signify the horrible for us to experience it."11 Here Barthes touches on a significant aspect of the challenge of representation: active verse passive responses. Seeing does not guarantee imagining, empathizing, or truly witnessing.

From the same standpoint, David Levi Strauss complements Barthes argument in discussing the difference between active and passive roles of interacting with a representation, and too often viewers remain passive. $\mathrm{He}$ explains that in these cases the images of violence and suffering intend to convey horror but fail to do so:

As we look at them, we are in each case dispossessed of our own judgment: someone has shuddered for us, reflected for us, judged for us; the photographer has left us nothing- except a simple right of intellectual acquiescence...such images do not compel us to action, but to acceptance. The action has already been taken, and we are not implicated. ${ }^{12}$

If the action is already completed as Strauss discusses - the action being to determine a point of view, decide what is important, or frame the understanding of the event- then the viewer, or reader, is unnecessary and can feel distant and irrelevant. This allows for the viewer to take a passive role, show limited concern, and continue on with life as if nothing has happened. Unfortunately, this is contrary to the intended aims of the representations, which are to bear witness, to bring political action, to ensure such suffering is not repeated. Yet, as Strauss explains, too often 
representations call for a passive position of the viewer in which he is able to remain distant from the atrocities witnessed.

Jaar requires an active position of the viewer as he does not display his photographs in his 1995 installation "Real Pictures" but rather only offers the viewer his captions for the photos. By hiding the images he forces the viewers to imagine the graphic scenes that Jaar had seen, which forces them out of passivity. The act of imagining also necessitates an element of responsibility for what they have imagined, how they have imagined it, and how they reflect upon it. When someone walked into his installation they would not see a single photograph but rather in their place would see stacks of boxes with captions written on top of them. Jaar "buries" sixty carefully chosen images in the black linen boxes. These boxes are silk-screened in white with descriptions of the images that are hidden inside. They are then stacked and arranged into monuments of different sizes. Jaar places emphasis on the experience of the viewer who has to carefully read each description and imagine not only the photograph but also the situation, the lives, and deaths of the people. The effect of the exhibit is "funereal" and the "silence of the gallery is deafening."13 Jaar encourages a relationship between the viewer and the event such that the person is emotionally affected and moved to empathize with the victims. This is a very different outcome than that against which Strauss, Barthes, and Jaar speak. Strauss asserts that "images of suffering and misery elsewhere in the world are used as reminders of what we are free from."14 Yet, Jaar refuses the safety of distancing oneself from the image seen as he never actually shows the image.

In addition to photography and journalism, questions of representation and witnessing are relevant issues addressed in French and Francophone literary studies. The study of representations of violence draws from these same journalistic questions of the consumption of images, the creation of a spectacle, the sensational and pornographic violence, and the domination of the victims through the representations. Aimé Césaire takes part in this conversation of ethical representations but does so specifically in the context of colonization. In the epigraph of Notebook of a Return to My Native Land he warned against the pitfalls of representations of violence, "most of all beware, even in thought, of assuming the sterile attitude of the spectator, for life is not a spectacle, a sea of grief is not a proscenium, a man who wails is not a dancing bear." Césaire does not simply warn those who portray suffering, but he speaks directly to the reader and thus cautions us all to be careful as we read the stories or see the images. He places the responsibility to avoid the objectification and dehumanization of victims, and the creation of a spectacle of the horrific events on the reader and not only the person who has portrayed the violence. Ethical representation of violence not only considers accuracy, efficacy, and how the violence is portrayed-avoiding degradation, or the point of the view of the author or 
artist- but also how the viewer is encouraged or discouraged to relate to and interact with the information given.

The important step taken by Jaar to force a closer, more active relationship of the viewer with the representation of genocide parallels Courtemanche's treatment of the Rwandan genocide in his hybrid text Un dimanche à la piscine à Kigali. Jaar places the onus on the viewer as an expression of ethical representation and begs the ethical spectatorship of the viewer. Likewise, Gil Courtemanche, a Canadian journalist who was in Rwanda during the genocide and who wrote a hybrid text mixing journalistic account with a fictional novel, implicates the reader, often that of a western audience, to interact directly with the text and take a more active role in the witnessing of the violence that occurred. Gil Courtmanche takes advantage of his profession as journalist in order to create a hybrid text, both fiction and first-hand account, that surpasses the actual events of the genocide and creates a narrative space in which no one escapes the guilt or the violence experienced in Rwanda.

In a warning to the reader in his preamble, Courtemanche discusses the hybridity of his novel and also testifies to the veracity of his report. He warns the readers not to assume that the descriptions of the violence and cruelty are embellished for effect:

Ce roman est un roman. Mais c'est aussi une chronique et un reportage. Les personnages ont tous existé et dans presque tous les cas j'ai utilisé leur véritable nom. Le romancier leur a prêté une vie, des gestes et des paroles qui résument ou symbolisent ce que le journaliste a constaté en les fréquentant. ${ }^{15}$

This novel is fiction. But it is also a chronicle and eye-witness report. The characters all existed in reality, and in almost every case I have used their real names. The novelist has given them lives, acts and words that summarize or symbolize what the journalist observed while in their company. ${ }^{16}$

These guidelines for the reader help to avoid the emotional and moral distancing that can occur when the atrocities of reality seem more like a horror film. However, in order to do justice to the events and victims, and have the possibility of preventing similar atrocities in the future, it is important that the reader/spectator does not allow the events to transform into the imaginary like a scary nightmare. Courtemanche stayed faithful to the actual stories and events, a task which has also helped him to comprehensively demonstrate the complexity of the situations and the people involved and encouraged the reader to stay in the discomfort of an unfortunate truth.

He offers an example of an ethical representation of the terrifying events in part because he presents the crimes as committed both by and 
against humanity as a whole, including the reader. He does not further perpetuate the racial stereotypes of Africans: either savage killer or worthless victim. Courtemanche refuses to further degrade the victims or to simplify the situation to make it seem like fictional horror, both of which would allow the reader to detach himself from the cruel reality. Instead, Courtemanche actually chooses to use voyeuristic literary strategy in order to implicate the reader in accusations against a world that failed in its response to the Rwandan genocide and to include the reader among the violated victims.

Courtemanche also wrote the screenplay for the movie version of his text, Un dimanche à Kigali, yet it lacks many of the aspects of that make the text an ethical representation. Because of the visual aspect a film brings, the film is necessarily much less explicitly violent than the novel. The result is the removal of the voyeuristic scenes that incriminate the reader, and that require the active participation of the reader, both of which are important in ethical representations. Also, the film does not give space for the voices of the victims to come through and tell their own stories. The audience hears about SIDA and Methode through the lens of Valcourt's camera after Methode's death rather than through Methode's own words coming from a place of strength. Also in the film, the audience witnesses the atrocities Gentille faced through flash-backs as the camera reflects what Valcourt is learning about what happened to her. Whereas in the text, Gentille tells her own story in a journal; despite the torture and violation she endured she has the strength to testify to the experiences, which guards her subjectivity rather than portraying her as simply the object of violence. Courtemanche succeeds in ethically representing the genocide in numerous ways in his text that unfortunately do not translate to the screen. The visual element produced a large challenge, as did shortening the text to fit into a feature length film. For these reasons, as well as the fact that a film automatically leans towards a more passive role of the viewer, I have chosen to focus on the text version as part of the discussion on audience participation as a necessary part of ethical representations of genocide.

The film version of Un dimanche highlights some of the challenges with actually seeing representations of violence, and Schnyder and ToudoireSurlapierre, in Voir et Être $V u$, further elaborate on this by discussing the connection between seeing and dominating. They posit that the viewer possesses a desire to destroy the object seen. The spectator's urge to look is based on a need for knowledge, which is connected to a desire to dominate and termed scopophilia. Schnyder and Toudoire-Surlapierre assert that this scopophilial desire leads to the destruction of the image. If domination stems from knowledge as discussed above, then the reader of Un dimanche also dominates over the victims because of his/her voyeuristic behavior, which has permitted him/her to possess intimate, shameful, degrading, and objectifying knowledge about the characters in the film. What is more 
powerful, though, is that the characters represent real people who were victims of the atrocities of the genocide. Schnyder discusses the tyrannical potential of the unbalanced gaze towards the "Other" by emphasizing the power one has when having the privileged position of knowledge through the gaze. Kelly Oliver, in Witnessing: Beyond Recognition, explains the relationship between knowledge, sexuality and domination in an apt way:

The instinct for mastery is nonsexual, [but] can fuse with sexuality secondarily to become sadism. Freud describes the instinct for knowledge and the instinct for mastery in terms of opposites activity/passivity; the aim of the instinct for mastery is actively to dominate or to destroy the object. ${ }^{17}$

Due to this complex relationship between the gaze, knowledge, and domination Courtemanche's readers are unavoidably implicated in the genocide because they are complicit to the violence being done to the characters, and thus they are part of the failure of humanity. Henceforth, the reader cannot maintain an outside position of judgment of the events. Thus, the text gives back the humanity to its characters that had been lost to the degrading violence, erasure of personal and collective history, and the obscene and sensationalized images.

Another area in which Courtemanche succeeds in his representation is by debunking the commonly held ideas that perpetrators of genocide are either monsters or savages and that the victims are helpless in need of Western saviors. These are both stereotypical images of not only the Hutu aggressors in the Rwandan genocide but also Africans and colonized people in general. This objectification in media is similar to the objectification of people discussed by Aimé Césaire in his discourses on colonization. He states that "radical objectification manifests as [...] contempt, mistrust, arrogance and degraded masses" and allows for "the irrational other [to be] devalued, abused, erased, or exterminated."18 If media representation perpetuates the negative impression of the people in question, it also contributes to the abuse they experience by propagating a lack of concern and self-complacency of the Western viewers, or even just by further degrading the victims themselves. Not only does he refuse to adhere to these stereotypes, Courtemanche actually succeeds in demonstrating how genocide is linked to the perceived superiority of one group to another that can come from these labels of inferiority. This is achieved by a narrative that illustrates that no group, person or country is outside of blame for similar ways of thinking. The characters in Un dimanche à la piscine à Kigali aptly demonstrate the universality of prejudice, the desire for power, and the perception of superiority, all of which lead to the violence that was seen in Rwanda. ${ }^{19}$

The stereotypes of helpless African in need of a savior, or aggressive, monstrous African, for instance, make up what is known as cultural 
violence, a concept coined by Johan Galtung in his essay entitled Cultural Violence. He explains that cultural violence is an invariant, which makes direct and structural violence look, even feel, right - or at least not wrong. Indeed, one of the reasons that genocide can occur is because the victims are dehumanized and made into animals, objects, villains, and enemies. Given that these ways of thinking bring about, or at the very least legitimize such violent behaviors, it is absolutely necessary to avoid the perpetuation of such beliefs, which allow for people to become objects and thus held outside the standards of moral treatment. Un dimanche à la piscine à Kigali transcends this reductionist depiction of genocide by complicating the roles of the characters to show the capacity of hatred and violence in all people. To further achieve this aim, he implicates international actors and even the reader of the novel in the genocide as well. Samantha Powers, in her article Bystanders of Genocide, suggests that Western prejudices towards the violent nature of tribal conflict in Africa contributed to the inaction of the United States in preventing or at least limiting the atrocities committed in Rwanda. Therefore, in representing the Rwandan genocide one also has to avoid the objectification of a group of people. Additionally, the representations must create a bridge between the genocidal behaviors, the implicated persons, and the readers who often are of Western origin. Un dimanche does just thatit surpasses the actual events of the genocide and creates a narrative space in which no one escapes the guilt or the violence experienced in Rwanda- not even the reader.

Courtemanche implicates the reader in the acts of genocide in three powerful ways, thus engaging the reader in such a way that he cannot remain distant, and he is forced to consider his own prejudices and responsibility in the propagation of violence. One, Courtemanche focuses on the universality of the conditions that lead to genocidal acts such as hatred, prejudice, and fear and then he utilizes narrative strategies to implicate the reader as a voyeur who imposes his own prejudices on the characters. Two, he establishes the problem of inaction through the historical perspective that places blame on Western countries and then implicitly includes the reader in this group because the reader passively witnesses the atrocities through the detailed and gruesome lens Courtemanche offers. Three, through the role as voyeur of rape the reader is further implicated because he contributes to the humiliation and degradation of victims, thus aiding in the use of rape as a genocidal weapon.

As well, Courtemanche defines the problem of the Rwandan genocide in universal terms to which everyone relates. He says that hate was the sickness that caused the slaughter to happen and that this root of genocide is something from which humanity in general suffers. As an example of this, we as readers participate in the hatred because of the way in which we respond to the media's portrayal of the genocide. Our disinterest and contempt can be seen in our inaction towards current injustice and violence, 
and it is even evident when we turn away from the gruesome pictures wondering when they will stop because we do not like how they make us feel. In this way we are no different from Valcourt and Raphael, two characters who wished that their close friend Méthode was already dead because they were tired of watching him suffer and wanted to continue with their own lives.

Courtemanche also identifies feelings of superiority as a root to the problem of genocide and demonstrates that no one is outside of this problem of superiority, which encourages the reader to renounce any such feelings that could otherwise contribute to an objectification of the victims by way of the reader's interactions with the text. He explains that the conflict between the Hutu and Tutsi had existed for centuries because of a longstanding battle in which both ethnic groups wanted to assert itself as superior. He thus insinuates that the Tutsi were actually no better than the Hutu murderers and thus complicates the binary roles of victim and perpetrator. Courtemanche also bridges the gap between the Rwandans and the Whites who also see themselves as superior. Courtemanche uses the opinion of Célestin, a Hutu, to underline the universality of feelings of superiority.

Il avait rapidement compris que les Blancs se croyaient supérieurs. Cela ne le dérangeait pas. De tout temps, des individus, des clans, des tribus avaient promené leur supériorité proclamée sur les collines et dans les vallées. Certains usaient de la force, d'autres du commerce, pour s'affirmer, mais toujours, chacun à sa façon. ${ }^{20}$

He quickly understood that the Belgians considered themselves superior. He was not upset about this discovery. From the beginning of time, individuals, clans, tribes had paraded their superiority, proclaimed it on the hills and in the valleys. Some used force and others used trade to assert themselves, but always, each in his own way and each on his own hill.21

Once again, the similarities between people are emphasized: everyone sees him or herself as superior, and thus everyone is guilty of the same sin that has led to genocide. He forces the reader to examine the truth because he erases the distance between us and the victims and aggressors of the rapes and murders.

Furthermore, as a Western audience, we too often passively accept the perceptions and point of view that we receive from representations of genocide in the media. These images are frequently limited to obscene, degrading, and objectifying perceptions that perpetuate the stereotypes about the evil, backward Africans who kill each other. I am not arguing that the images themselves are manipulated or falsified in any way. However, they do provide a limited view of genocide and of the people associated with the events, which can conceptually transform people into objects thus rendering the event itself a spectacle. This objectification in media is similar 
to the objectification of people discussed by Aimé Césaire who states that "radical objectification manifests as [...] contempt, mistrust, arrogance and degraded masses" and allows for "the irrational other [to be] devalued, abused, erased, or exterminated." 22 If media representation perpetuates the negative impression of the people in question, it also contributes to the abuse they experience by propagating a lack of concern and selfcomplacency of the Western viewers, and also by further degrading the victims. This is fundamentally similar to the Hutu soldiers who killed their Tutsi neighbors and friends because they believed the propaganda that they were told on Rwandan radio: the root of all their problems was the Tutsis who were nothing more than cockroaches. Yet, unfortunately, Western representations of the violence that occurs in African countries, and other developing countries, can be little more than propaganda supporting the superiority of the Western world and the inferiority of Africa and Africans who are responsible for the genocide. Aedín Ní Loingsigh, in her article Lying to tell the truth: fiction and the Rwandan genocide in Véronique Tadjo's L'Ombre d'Imana, states:

Qualifications such as "savage", "barbaric" and "senseless", which were frequently used to describe the violence, pointed to a particular Western bias in portrayals of African identity and underlined a reluctance to examine events within the context of Rwanda's complex history. Although the violence was frequently branded as incredible, it was also treated as known and inevitable, and consequently unworthy of much attention. ${ }^{23}$

This explanation helps us understand that by painting a negative picture of a group of people the representation of violence can further stereotypes and can even lead to violence because stereotypes and prejudices in art and literature make up the cultural violence that legitimizes direct violence.

Affected by these stereotypes promoted in representations of violence and the genocide in Rwanda, the lector reads and reacts to the detailed descriptions of both sex and violence through the lens of our his own biases and preconceptions. This voyeuristic role of the reader can thus result in continued objectification and degradation. However, because of the relationship Courtemanche has created between the reader and the text, and the strategies he has employed which cause the reader to question his own role, the reader is likely to reflect upon his role as voyeur and ultimately self-condemn for judgments passed rather than further continue on the path to objectify the victims. For example, in the scene where Méthode is living his last moments in the hotel room, the reader intrudes on an intimate sexual and emotional moment. We are the uninvited spectator who perhaps feels uncomfortable, aroused, or places judgment. There are almost two pages of a detailed description of the sexual acts Agathe performs with and for Méthode before he dies. The details are intimate and, in reading them, we 
invade the privacy of the characters and feel uncomfortable with knowing too much. This is especially true because Courtemanche indicated in his preface that the characters are based on real people. Courtemanche also testifies to the veracity of his report. While the sexual pleasure given to Méthode was watched by the friends and family, we are not friends or family who participate in the sacredness of the celebration. We are outsiders with a different set of cultural norms. We are concerned that Agathe will end up getting AIDS. We are uncomfortable with the fact that Méthode's mother is present and even places her hand on Méthode's stomach so that Agathe could more easily engage in oral sex. We may also impose beliefs that sexual intimacy should be enjoyed within the context of a monogamous relationship or in private. At the very least we wrestle with these prejudices as we continue to "watch" and as we place judgment upon the situation, we risk cheapening and degrading the sacredness of the moment and reduce it to pornographic.

Another powerful example of how narrative strategy causes the reader to be implicated as culpable in the atrocities of genocide, and thus more closely aware of the complex reality of the violence, is through the voyeurism in the scene where Cyprien's wife Georgina is raped and then she and Cyprien are both murdered. Courtemanche pushes the boundaries of his text by giving a detailed account of the forced rape between Cyprien and his wife. So much detail is given that it actually provides the reader with the violent, obscene images associated with the event. With a gun to his head, Cyprien undresses his already violated, bloody wife. The narration continues with emphasis on the gentleness and delicateness with which he proceeds to in essence rape her. Not only is she not consenting but she has already been brutally beaten, her breast cut off and repeatedly raped that prolonging her inevitable death is itself torture. Yet Cyprien kisses the entirety of her body and the angry soldier attacks him with a machete. This does not stop him. He continues to make love to his wife, engaging in oral sex for the first time and Courtemanche recounts it all in detail. The reader is present there with the soldiers, as spectators for what should be an incredibly intimate moment but the experience is perverted in the context of such violence. Cyprien then penetrates his wife, and just before ejaculating, he is murdered. And again, we are witness. We have been witness to the whole event and did nothing but writhe in our own discomfort. In the same way that Courtemanche accuses the foreign world of being witness without having acted, the reader is now implied as a guilty bystander.

It is not only the violent nature of rape that stole their pleasure; we have as well because our presence adds to the shame and humiliation and thus contributes to one of the goals of rape. Rape has historically been used as a weapon in war in order to degrade women. Arlette Farge and Cecile Dauphin discuss the use of rape as a weapon of war in their text De la violence et des femmes and attest to its historical use as a proof of the 
inhumanity of the enemy. The women victims of rape are reduced to objects symbolizing domination of men and their aggressive power. Farge and Dauphin discuss the systematic use of rape as a weapon of war in both the Spanish Civil War and in former Yugoslavia and in both situations rape was used to humiliate and dishonor the victim, and to create a climate of terror. The shame associated with the rape played a significant role in the power of rape as a weapon in war. In the case of Georgina, she lost her breast, was raped by her own husband on her death bed so that she was fully stripped of her identity as a woman in addition to being murdered. As spectators we contributed to her degradation because we watched her dignity being taken away. Not only does Courtemanche testify to the veracity of his accounts, and thus this horrific rape and murder, but the gruesome details are representative of many real events that, as a nation, we stood by and allowed to occur. As reader, we must begin to examine our own responsibility to speak out and act against the violence that we now more completely understand.

However, as readers we are not only the aggressors who stand next to the soldiers and violate the victims; we are also victims to the violence of the text. We are forced to be among the murderers who are watching. Over and over again the reader is exposed to the graphic details that paint obscene pictures. We see the blood and tears. We feel nauseated and we lose our breath. The reader is physically affected by the violence described and by the violent nature of the language itself. The following citation, which describes the death seen by Valcourt on the street, demonstrates this violent nature of the language: "Les cadavres des hommes faisaient des taches noir et blanc, les seins dénudés, la culotte rose ou rouge encerclant les genoux. Valcourt les voyait trembler, les entendait râler et gémir." 24 "The men's bodies, clothed, made black and white patches; the women's were exposed, legs spread, breasts bared, pink or red underpants around their knees. Many were still alive. Valcourt could see them tremble and hear them rattle as they breathed and moaned." 25 Courtemanche purposefully includes sound and color to increase the visual imagery such that multiple senses of the reader are attacked. In this part of the citation it is the rhythm of the language that is so vicious.

On tuait les hommes, d'un coup de feu ou d'un coup de machette, savant et précis. Mais les femmes n'avaient pas droit à une mort claire et nette. On les mutilait, on les violait, mais on ne les achevait pas, comme on l'aurait fait avec des animaux blessés. On les laissait aller au bout de leur sang, sentir venir la mort râle par râle, crachat par crachat, pour les punir d'avoir mis au monde tant de Tutsis, mais aussi pour les punir de leur arrogance car, à tous ces jeunes qui tuaient, on avait raconté que la femme tutsie se croyait trop belle pour eux. ${ }^{26}$ 
The men were killed skillfully and accurately with a single shot or machete stroke, but the women didn't have the right to a quick, clean death. They were mutilated, tortured, raped, but not finished off as the killers would have done with wounded animals. They were allowed to bleed to death, to feel death coming rattle by rattle, gob by gob of blood-filled spit, to punish them for having brought so many Tutsis into the world, but also to punish them for their arrogance, for the young killers had been told that Tutsi women considered themselves too good for Hutus. ${ }^{27}$

There are long, never-ending sentences composed of shorter phrases. This structure parallels the way in which the women are killed. Blow by blow, one form of torture after another, the women slowly meet their death. As the quote states, not even hurt animals would be left to suffer that way. However, in the case of the Rwandan genocide the women were considered less valuable then animals, and were treated with less respect. The style of writing here matches the slow, painful process of the women losing their lives, and with each additional phrase, the reader also feels the blows of hatred.

Courtemanche breaks down the binary separation of victim and perpetrator, Hutu and Tutsi, African and Westerner to demonstrate a complexity that is closer to the reality of human existence. Courtemanche's choice to implicate the reader in accusations against a world that failed in its response to the Rwandan genocide, and to include the reader among the violated victims, truly makes his work stand apart. Un dimanche à la piscine à Kigali succeeds in representing the horrors committed at Kigali because he presents them as crimes both by and against humanity as a whole and challenges stereotypes and fears of evil Rwandan/African perpetrators or helpless Rwandan/African victims that contribute to the legitimization of violence. In the following famous quotation Arthur Koestler brings to our attention the fact that language itself is a weapon that can cause much harm. He states, "Wars are not fought for territory, but for words. Man's deadliest weapon is language. He is susceptible to being hypnotized by slogans as he is to infectious diseases. And where there is an epidemic, the group mind takes over." 28 This astute explanation of wherein lies the real weapon also implies the possibility that acts of extreme violence could occur anywhere, with anyone as the antagonist. This is a concept that is maintained and further developed in Courtemanche's hybrid novel. The narrator states:

Nous pouvons tous nous transformer en assassins, avait toujours soutenu Valcourt, même l'être le plus pacifique et le plus généreux. Il suffit de quelques circonstances, d'un déclic, d'une faillite, d'un patient conditionnement, d'une colère, d'une déception...Chacun possède dans ses gènes toute le Bien et tout le Mal de l'humanité. ${ }^{29}$ 
We can all turn into killers, Valcourt had often maintained, even the most peaceful and generous of us. All it takes is a certain circumstance, something that clicks, a failing, a patient conditioning, rage, disappointment...All the Good and Evil of humanity is in our genes. ${ }^{30}$

This notion that everyone possesses the possibility for good and evil reclaims the humanity in situations of genocide; the extreme violence occurs because of an extreme, complex situation, not because Africans, or Germans, Armenians or any other group are particularly evil.

This rejection of stereotypes and prejudice is an essential part of an ethical reading of representations of violence, suffering, or of marginal groups in general. Kelly Oliver in Witnessing: Beyond Recognition in her discussion of the value of witnessing as well as the potential pitfalls associated there within defines a responsibility and obligation of the reader or viewer to see an investment of oneself in another- in this context the victims and perpetrators of the Rwandan genocide. She extols that it is not a debt but rather an ethical duty to see oneself in connection with others and that this type of witnessing violence can avoid the potential dehumanizing effects that are possible. "Seeing investments in each other should prevent what Williams calls 'pornographic seeing,' which makes the other into an object of spectacle, there for the viewer's pleasure, possessed by the subject's gaze...Pornographic seeing denies the seer's responsibility for seeing by ignoring the seer's connection to what he sees." 31 Oliver warns against seeing as possessing, bearing witnessing as a way to further objectify or victimize and calls on the responsibility of the viewers or readers to form a connection and see investments in others. Such behaviors are important but need to be encouraged by the representations themselves. Jaar and Courtemanche require their audience to interact with the subject from a position of compassion and understanding. Not only do they pay attention to how they depict the genocide, but also they pay close attention to how they engage their audience to take responsibility for their part of the ethical representations.

${ }^{1}$ All translations are my own unless otherwise noted.

${ }^{2}$ Roskis, E. Retour sur une image choc. Téléscope, 81, October 1994.

${ }^{3}$ Ibid.

${ }^{4}$ I use the term pornographic to describe violence, even outside the realm of sexuality, in order to emphasize the obscene, degrading nature of the images whose intended purpose is to 
sensationalize its subject. It garners attention of the viewer/reader but also objectifies its subjects. The term pornographic violence also warns of the fantastical elements of the representation that could distance the viewer/reader from the reality of the situation. Additionally, this term carries the implication that the viewer takes at least a small amount of shameful pleasure from seeing the image, enjoying perhaps the objectifying violence of the images. I will address this aspect in more depth as I discuss spectator responsibility. This concept of pornographic violence will also be further developed when discussing the Un dimanche à la piscine à Kigali in which Gil Courtemanche describes the violent, sexual acts of rape and mutilation during the genocide with such vivid detail that it can even be seen as pornographic in a more traditional sense.

${ }^{5}$ Roskis, E. Retour sur une image choc. Téléscope, 81, October 1994.

${ }^{6}$ Sontag, Susan. Regarding the Pain of Others. 1st Picador ed. (New York: Picador, 2004), p 7.

7 Ibid, 8.

${ }^{8}$ The absence of representation in public media during the genocide is, of course, a failure in itself and also a reflection of that which most interests the public as the United States, for example, was wrapped up in 24 hour coverage of the OJ Simpson trial during this time.

${ }^{9}$ Gallo, Rubén. "Representation of Violence, Violence of Representation" Trans 3/4, 57.

10 Audouin-Rouzeau, Stéphane. "Violences extrêmes de combat et refus de voir", Revue internationale des sciences sociales 4/2002 ( $\left.n^{\circ} 174\right), 544$.

${ }^{11}$ Barthes, Roland. The Eiffel Tower, and Other Mythologies. 1st American ed. (New York: Hill and Wang, 1979), p 77.

12 Strauss, David Levi. A Sea of Griefs Is Not a Proscenium: On the Rwanda Projects of Alfredo Jaar. NKA (Brooklyn, N.Y.) 01/01/1998, Issue: 9. 38.

$13 \mathrm{lbid}, 42$.

$14 \mathrm{Ibid}, 38$.

${ }^{15}$ Courtemanche, Gil. Un dimanche à la piscine à Kigali (Paris: Denoël, 2009), p 12.

${ }^{16}$ Courtemanche, Gil. A Sunday at the Pool in Kigali (New York: A.A. Knopf, 2003).

17 Oliver, Kelly. Witnessing : Beyond Recognition (Minneapolis: University of Minnesota Press, 2001), p 7.

18 Césaire Aimé, Discourse on Colonialism, trans. Joan Pinkham (New York: Monthly Review Press, 1972), p 42.

19 The relationship between Justin, a Rwandan pool man who worked at the hotel, and the white guests of the hotel demonstrates this universality of prejudice and hatred, and the violence that ensues. Justin had many opportunities to have sexual intercourse with these women because they fantasized about the stereotypes of a hyper-virile and sexual African man. Courtemanche does not only blame the Western women with their stereotypical views and the ways in which they seek to use Justin to fulfill their fantasies, but Justin is also guilty of hatred and violence. "Chaque fois qu'il baisait une Blanche, et il y en avait tellement qui promenaient leur corps incertain, leurs envies dissimulées, leurs fascinations pour le nègre barbare et puissant, chaque fois il se vengeait du fait d'être garçon de piscine et simple objet de convoitise sexuelle de la 
part des maîtresses. Il se vengeait aussi du fait d'être noir. Il se comportait avec les Blanches comme elles rêvaient qu'il le fasse, en brute animale, puisqu'il n'était pas vraiment un humain" (Courtemanche, Un dimanche, 171). Justin was sure to take revenge on these objectifying women. After having played to the fantasies of the women he refused to have sexual relations with them, which was his own form of psychological torture; an when he did give into their desires he demonstrated his own hatred for them by intentionally giving them HIV.

${ }^{20}$ Courtemanche, Gil. Un dimanche à la piscine à Kigali, 36.

${ }^{21}$ Courtemanche, Gil. A Sunday at the Pool in Kigali, 23.

22 Césaire, Aimé, Discourse on Colonialism, 42.

${ }^{23}$ Milne, Lorna. Postcolonial Violence, Culture and Identity in Francophone Africa and the

Antilles (Oxford: Peter Lang, 2007), p 83.

${ }^{24}$ Courtemanche, Un dimanche, 278.

${ }^{25}$ Courtemanche, A Sunday, 220.

${ }^{26}$ Courtemanche, Un dimanche, 278-279.

27 Courtemanche, A Sunday, 220.

${ }^{28}$ Thompson, Allan. The Media and the Rwanda Genocide (London: Pluto Press, 2007), 308.

${ }^{29}$ Courtemanche, Un dimanche, 136.

${ }^{30}$ Courtemanche, A Sunday, 120.

${ }^{31}$ Oliver, Witnessing : Beyond Recognition, 156-157. 